\title{
Physiological Response of Upland Rice Varieties to Furrow with Organic Matter on Agroforestry System with Kayu Putih (Melaleuca leucadendra L.)
}

\author{
Puji Lestari Tarigan ${ }^{*}$, Tohari $^{1}$ and Priyono Suryanto ${ }^{2}$ \\ ${ }^{1}$ Department of Agronomy, Faculty of Agriculture, Universitas Gadjah Mada, Yogyakarta, Indonesia; \\ ${ }^{2}$ Department of Silviculture, Faculty of Forestry, Universitas Gadjah Mada, Yogyakarta, Indonesia \\ *Corresponding author: tari_siriuz@ymail.com
}

\begin{abstract}
Drought is one of the major limitations in dry land cultivation. Drought affects plant physiology processes such as photosynthesis, respiration, mineral and water transportation, and transpiraton, briefly called drought stress. Drought stress can be avoided by managing environment. Furrow containing organic matter for rain fed rice has been the subject of many studies, with special emphasis on soil moisture. This research is aimed to know the effects of the furrow containing organic matter on physiological responses of several upland rice varieties on agroforestry system based on kayu putih (cajuput). The experimental design applied the strip plot design. The vertical factor is the furrow system of treatment consisting of 2 levels i.e. without furrow + without organic matter and furrow + organic matters. The horizontal factors are the upland rice varieties consisting of 3 varieties i.e. Situ Patenggang, Situ Bagendit and Ciherang. The collected data were analyzed by Analysis of Variance (ANOVA) applying a level of significance $\alpha=5 \%$. Whenever significant differences among treatments were found, further analysis was carried out by applying the Tukey's HSD (Honestly Significant Difference) test $\alpha=5 \%$ levels. The result shows that drought affects plant physiology and can be avoided by using furrow containing organic matters. Situ Patenggang with furrow containing organic matters has the higher physiology capability, it had photosynthesis $387.18 \mu \mathrm{mol} \mathrm{CO}_{2}$ per clump s ${ }^{-1}$, transpiration $3038.50 \mathrm{mg}$ per clump per second and $\mathrm{CO}_{2} 721.11 \mathrm{~mol} \mathrm{CO} 2$ clump per mol. There different plant requirements for $\mathrm{Cu}$ between varieties.
\end{abstract}

Keywords: agroforestry, furrow, kayu putih, rainfed, upland rice

Cite this as: Tarigan, P. L., Tohari, \& Suryanto, P. (2019). Physiological Response of Upland Rice Varieties to Furrow with Organic Matter on Agroforestry System with Kayu Putih (Melaleuca leucadendra L.). Caraka Tani: Journal of Sustainable Agriculture, 34(2), 223-231. doi: http://dx.doi.org/10.20961/carakatani.v34i2.29786

\section{INTRODUCTION}

Change in population affects the arable land (Lopez et al., 2001; Kavita et al., 2015). The rate of agricultural land conversion in Indonesia is 187.720 ha per year and most conversion is for housing and industrial purposes (Agus et al., 2006; Rondhi et al., 2018). The agricultural land conversion threatens food supply (Azadi et al., 2011). Rice is one of the largest commodities, because it is needed in some countries. Besides, the land conversion also occurs in forest area.
Deforestation is mostly done for agriculture purpose. This case needs solutions to provide the means of forest conservation and to assure that agriculture can still take place.

Integration of agriculture and forest can be the solution to get sustainability on food and environment. The cultivation of some food crops in forest area has been going on for a long time. Agroforestry is an optimal and sustainable land use, by combining forestry and agricultural activities on the same land by paying attention to

\footnotetext{
* Received for publication May 04, 2019

Accepted after corrections August 10, 2019
} 
the environmental, physical, social, economic and cultural conditions of the participant (Perum Perhutani, 2002; Mayrowani and Ashari, 2011).

Agroforestry system is an effort to restore land, increase food production and conserve forest land. This system develops in the community according to the natural conditions and market needs, and is in line with the development of people's experience for years from one generation to another. The development of this system has had a positive impact on economic, social and environmental growth. Upland rice, corn and soybeans are the potential food crops to be developed in forest areas. The development of these commodities is one of the strategies of the Ministry of Agriculture to achieve food selfsufficiency.

Intercropping is a simple form of agroforestry system, where trees are intercropped with one or more types of seasonal plants. Trees can be planted as a fence around a plot of food crops randomly in a plot of land or with other patterns such as marching in an array to form an aisle or fence (Hairiah et al., 2003; Gunawan et al., 2015). Agroforestry is a land use system that supports sustainable agriculture, has a variety of production and conservative to environment and social conditions and ensures the economy and food security (FAO, 1989; Suryani and Dariah, 2012). Agroforestry system represents integrated land concept of using combination of agriculture and forestry in a sustainable production system (Smith, 2010). Some plants that can be cultivated in intercropping are upland rice, cassava, soy bean, etc.

Cajuput is one of forest plants which can be planted with agroforestry system. The spacing of Cajuput with a wider size provides intercropping field. Planting intercropping plants on Cajuput is considered beneficial, because the canopy grows vertically and is not too wide, and will be pruned the leaves and branches when harvested. Cajuput is a Non-Timber Forest Products (NTFPs) commodity. This plant can grow in various land conditions, including marginal land. Cajuput can live on land with high lime content, low to high salt content and on land with low rainfall or dry land.

Upland rice is the one of the sources of Indonesia's rice production. Upland rice productivity is only 3.3 tons $\mathrm{ha}^{-1}$ and lower than paddy which reaches 5.3 tons $\mathrm{ha}^{-1}$ (Kementerian
Pertanian, 2016). Situ Patenggang can reach production of 4.6 dry-milling rice, which is drought tolerant and resistant to blast disease. Situ Bagendit can reach production of 4 tons ha ${ }^{-1}$ (BB Padi, 2007; Putra, 2012). These superior varieties are suitable to be developed in upland areas. The lowland rice Ciherang, can grow on dry land with shifting cultivation in the Pematang Sawah area, Tanggamus Regency, which grows well and yields reaching 3.5-4 tons ha ${ }^{-1}$ (Hafif, 2016).

Cultivating intercropping food crops on dry land must consider the available amount of water. Upland rice growth in dry land has some influencing factors. Drought stress is the most principal factor that must be avoided. Water is an important factor for rice, especially in the generative phase. Upland rice requires adequate water availability in root zone. In dry land, soil moisture depends of rainfall. To optimize water availability and soil moisture, rainwater harvesting is necessary. Harvesting of water is a technique of storing rainwater and stabilizing soil moisture.

Water is the largest part of a plant protoplasm, which is around $85-90 \%$ and functions as an important reagent in photosynthesis and other hydraulic processes. Water is also a solvent for salts, gases and other materials that move into plants through cell walls and other essential tissues. This is to ensure the existence of turgidity, cell growth, stability of leaf shape, the process of opening and closing the stomata and the continuity of the movement of plant structures (Asfafuddin and Muatsih, 2015).

On dry land, rainfall and soil holding water capacity are main factors that determine the success of food production. To overcome the food production can be done using superior varieties, the right planting time and conservation of surface water (Idjudin and Marwanto, 2008). To date, furrow has only been used as drainage, but has not been used to store water. Optimization of the use of furrow can serve as rainwater harvesters and is supported by organic matters from around the land. Organic matters are material derived from the remains of living things. Organic matters have the ability to absorb water with a capacity that exceeds their weight. Furrow containing organic matters expected can increase infiltration and reduce surface run off. By increasing soil moisture can support plant growth. 


\section{MATERIALS AND METHOD}

The research was conducted from March to August 2018 in Petak 83 Menggoran Forest Resort (RPH Menggoran), Playen Forest Section (BDH Playen), Yogyakarta Forest Management District (KPH Yogyakarta), Gunung Kidul Regency, Yoyakarta Special Region. In addition to field observations, laboratory observations were also carried out at the Soil Laboratory, Plant Science Laboratory and Ecology Laboratory of the Faculty of Agriculture, Universitas Gadjah Mada, Yogyakarta. Kayu putih planted by KPH Yogyakarta is on $4 \mathrm{~m} \times 2 \mathrm{~m}$ plant spacing. Organic matter results from remaining plants around the land.

The field experiment used strip plot design, i.e.: 1) furrow as vertical factor (consisting of without furrow + without organic matters and with furrow + organic matter) and 2) varieties as horizontal factor (consisting of Situ Patenggang, Situ Bagendit dan Ciherang). There were 6 treatment combinations that were replicated for 3 times, so there were 18 trial units.

Furrows are made using rectangular paralon (PVC pipe) with a size of $33 \mathrm{~cm} \times 12.5 \mathrm{~cm} \times 15$ $\mathrm{cm}$. Furrows are placed four units in each plot, which is between the fourth and fifth plant rows and between the seventh and eighth rows in plot. The furrows were filled with organic matters, remnants of vegetation from the area around the experiment site. The weight of organic material used in the treatment of organic in each furrow is $\pm 10.3 \mathrm{~kg}$ or 41.2 tons $\mathrm{ha}^{-1}$. The remains of vegetation are in the form of corn residue from the previous crop.

Plant maintenance consisted of fertilizing, weed, pest and disease control. Fertilization was done three times. The fertilizers applied in 2 WAP (Weeks After Planting) were Urea $60 \mathrm{~kg} \mathrm{ha}^{-1}$, SP$3614.7 \mathrm{~kg} \mathrm{ha}^{-1}$ and $\mathrm{KCl} 34.4 \mathrm{~kg} \mathrm{ha}^{-1}$. In 5 WAP were Urea $69.4 \mathrm{~kg} \mathrm{ha}^{-1}$ and $\mathrm{KCl} 34.4 \mathrm{~kg} \mathrm{ha}^{-1}$. In addition, those in $8 \mathrm{WAP}$ were Urea $69.4 \mathrm{~kg} \mathrm{ha}^{-1}$, SP-36 $14.7 \mathrm{~kg} \mathrm{ha}^{-1}$ and $\mathrm{KCl} 34.4 \mathrm{~kg} \mathrm{ha}^{-1}$. Weed, pest and disease control was in accordance to integrated pest and disease management.

The Observation included photosynthesis rate, transpiration rate, carbon dioxide rate, copper $(\mathrm{Cu})$ tissue content and stomatal density. Observation of photosynthesis and carbon dioxide rate used Photosynthetic Analyzer Li-Cor tipe LI-6400 (Soleh, 2017) and transpiration used cobalt chloride paper method (Loveless, 1987; Sugiarto,
2018). Then the result was multiplied with leaf area to get result per clump. Observation of $\mathrm{Cu}$ content of tissues using wet digestion method and $\mathrm{Cu}$ concentrations was determined by atomic absorption spectrophotometry (Balai Penelitian Tanah, 2009). Observation of stomatal density was done using microscope 100x magnification integrated with Image Raster (Stace, 1965; Astuti, 2018) and the result was multiplied with leaf area to get result per clump.

Obtained data from observations were analysed using Analysis of Variance (ANOVA) according to split plot design using SAS 9.4. software for Windows. The significance difference variable continued by Tukey's HSD (Honestly Significant Difference) test $\alpha=5 \%$ levels.

\section{RESULTS AND DISCUSSION}

As shown by Table 1, there was positive interaction in photosynthesis, transpiration and carbon dioxide rate. Situ Patenggang with furrow and organic matter has the highest photosynthesis and carbon dioxide rate than other varieties. Ciherang with furrow and organic matter has the highest transpiration rate.

The plant needs certain amount of water for growing well and the amount varies in each other. Yoshida (1981) and Rosadi (2013) have stated that, rice needs water from $180-300 \mathrm{~mm}$ per month to produce well, if water is not available, the growth and development will be disrupted. The plant roots' absorption of water depends on the soil moisture (Dwidjoseputro, 1985; Rosadi, 2013). The cell water content must be optimum to ensure the effect of stress which will reduce metabolic processes and limit plant growth (Gardner, 1991; Anshar et al., 2011).

The photosynthesis rate involves various enzymes and is related to the temperature of the plant. The role of water as temperature regulator also affects the rate of photosynthesis. Quilambo and Scott (2004) and Rosadi (2013) have stated that, the photosynthesis process in most plants will begin to be depressed if the relative moisture content of the leaves is lower than $70 \%$, so the plant needs to do regulation. Reducing photosynthesis under drought stress is by closing stomata, associated with a decrease in internal $\mathrm{CO}_{2}$ concentration and inhibits total photosynthetic metabolism (Cornic, 2000; Maisura et al., 2015). The use of furrow containing organic 
matter as water storage can support plant photosynthesis. Situ Patenggang and Situ Bagendit varieties with furrow + organic matter shows the higher photosynthesis rate, Situ Patenggang and Situ Bagendit are able to utilize a limited amount of water due to the lack of rainfall in the anabolic process. Water availability is very important for plants to dissolve nutrients and transport assimilates and the main constituents of protoplasm and regulate plant temperature. The lower amount of ground water will inhibit the transport of nutrients in the process of photosynthesis, thus affecting crop production (Salisbury and Ross, 1997; Maryani, 2012).

Transpiration is the process of loss of water vapour through plant tissue. This process affects the rate of absorption of water by the transport system. Drought stress occurs, the temperature tends to increase, increasing the rate of transpiration. Ciherang shows the highest transpiration rate, but if it is associated with adaptability, this indicates the sensitivity of plants to the condition of limited amount of water. Plants that have the ability to avoid the effects of stress will tend to close the stomata to reduce the rate of loss of plant's water content and increase cell osmotic potential. When plant encounters drought stress, it will use more than one mechanism of defend (Mitra, 2001; Efendi, 2009). One of the mechanism adaptations in overcoming drought stress is regulating transpiration (Fischer and Fukai, 2003; Sujinah and Jamil, 2016).

Table 1. The interaction of furrow and varieties on photosynthesis rate, transpiration and $\mathrm{CO}_{2}$

\begin{tabular}{|c|c|c|c|c|}
\hline \multirow{2}{*}{ Treatment } & \multicolumn{3}{|c|}{ Varieties } & \multirow{2}{*}{ Mean } \\
\hline & Situ Patenggang & Situ Bagendit & Ciherang & \\
\hline Photosynthesis rate & \multicolumn{3}{|c|}{$\mu \mathrm{mol} \mathrm{CO} \mathrm{CO}_{2}$ per clump s ${ }^{-1}$} & \\
\hline Without furrow + without organic matter & $179.63^{\mathrm{bc}}$ & $149.14^{\mathrm{cd}}$ & $88.52^{\mathrm{d}}$ & $139.10^{\mathrm{b}}$ \\
\hline Furrow + organic matter & $387.18^{\mathrm{a}}$ & $350.04^{\mathrm{a}}$ & $238.38^{\mathrm{b}}$ & $325.20^{\mathrm{a}}$ \\
\hline Mean & $283.41^{\mathrm{a}}$ & $249.59^{\mathrm{b}}$ & $163.45^{\mathrm{c}}$ & + \\
\hline Transpiration rate & \multicolumn{3}{|c|}{ mg per clump per second } & \\
\hline Without furrow + without organic matter & $1685.80^{\mathrm{b}}$ & $1949.93^{\mathrm{b}}$ & $1521.12^{\mathrm{b}}$ & $1718.92^{\mathrm{b}}$ \\
\hline Furrow + organic matter & $3038.50^{\mathrm{a}}$ & $2894.24^{\mathrm{a}}$ & $3112.61^{\mathrm{a}}$ & $3015.13^{\mathrm{a}}$ \\
\hline Mean & $2362.17^{\mathrm{a}}$ & $2422.07^{\mathrm{a}}$ & $2316.87^{\mathrm{a}}$ & + \\
\hline Carbon dioxide rate & \multicolumn{3}{|c|}{$\mathrm{mol} \mathrm{CO}_{2}$ clump per mol } & \\
\hline Without furrow + without organic matter & $378.94^{\mathrm{bc}}$ & $312.29^{\mathrm{c}}$ & $182.72^{\mathrm{d}}$ & $291.31^{\mathrm{b}}$ \\
\hline Furrow + organic matter & $721.11^{\mathrm{a}}$ & $658.15^{\mathrm{a}}$ & $456.33^{\mathrm{b}}$ & $611.86^{\mathrm{a}}$ \\
\hline Mean & $550.02^{\mathrm{a}}$ & $485.22^{\mathrm{b}}$ & $319.53^{\mathrm{c}}$ & + \\
\hline
\end{tabular}

The $\mathrm{CO}_{2}$ content indicates the amount of $\mathrm{CO}_{2}$ that can be absorbed by plants on photosynthetic activity needs. The amount of $\mathrm{CO}_{2}$ contained in leaves is influenced by the availability of $\mathrm{CO}_{2}$ in the atmosphere and other environmental condition. Stomata activity as a place of entry of $\mathrm{CO}_{2}$ and other gases also affects the amount of $\mathrm{CO}_{2}$ contained in the leaves.

Situ Patenggang with furrow + organic matter varieties have the highest $\mathrm{CO}_{2}$ absorption. It happens because the soil moisture espouses the gas exchange activity of plant. Without furrow + without organic matter as indicate as drought stress occurs, plants reduce the rate of water loss by narrowing or closing the stomata. In addition, an increase solute occurs to balance the osmotic potential around the cell. Mapegau (2006) and Felania (2017) have stated that water stress causes the plants to close stomata due to a decrease in leaf cell turgor, the closing stomata inhibits the amount of $\mathrm{CO}_{2}$ that can enter the leaves.

Rosenberg et al. (1983); Donggulo et al. (2017) have stated that the photosynthesis rate in the canopy is influenced by the availability of $\mathrm{CO}_{2}$ around the leaves. According Halder and Burrage's (2004) research, the internal of $\mathrm{CO}_{2}$ concentration did not change indicating the decrease in photosynthesis was due the effect of water deficit. Accumulation of abscise acid (ABA) under drought stress was to reduce stomatal aperture, increasing assimilation rate due to decrease of $\mathrm{CO}_{2}$ intercellular.

The occurrence of drought generally causes decrease of transpiration rate, the stomata is closed, the entry of $\mathrm{CO}_{2}$ is blocked and so the availability of $\mathrm{CO}_{2}$ in the leaves lowers and decreasing photosynthesis rate (Nayyar and Gupta, 2006; Sarawa et al., 2014). 
Table 2. The effect of of furrow and varieties on stomatal density and $\mathrm{Cu}$ in plant tissue

\begin{tabular}{|c|c|c|c|c|}
\hline \multirow{2}{*}{ Treatment } & \multicolumn{3}{|c|}{ Varieties } & \multirow{2}{*}{ Mean } \\
\hline & Situ Patenggang & Situ Bagendit & Ciherang & \\
\hline Stomatal density & \multicolumn{3}{|c|}{ number of stomata per clump } & \\
\hline Without furrow + without organic matter & $966.11^{\mathrm{a}}$ & $987.21^{\mathrm{a}}$ & $919.22^{\mathrm{a}}$ & $954.50^{b}$ \\
\hline Furrow + organic matter & $1545.92^{\mathrm{a}}$ & $1472.32^{\mathrm{a}}$ & $1120.63^{\mathrm{a}}$ & $1379.50^{\mathrm{a}}$ \\
\hline Mean & $1256.02^{\mathrm{a}}$ & $1225.22^{\mathrm{a}}$ & $1019.91^{\mathrm{a}}$ & - \\
\hline $\mathrm{Cu}$ & \multicolumn{3}{|c|}{$\mathrm{ppm}$} & \\
\hline Without furrow + without organic matter & $0.95^{\mathrm{a}}$ & $0.78^{\mathrm{a}}$ & $1.10^{\mathrm{a}}$ & $0.95^{\mathrm{a}}$ \\
\hline Furrow + organic matter & $1.21^{\mathrm{a}}$ & $1.23^{\mathrm{a}}$ & $0.86^{\mathrm{a}}$ & $1.10^{\mathrm{a}}$ \\
\hline Mean & $1.08^{\mathrm{a}}$ & $1.01^{\mathrm{a}}$ & $0.98^{\mathrm{a}}$ & - \\
\hline
\end{tabular}

According to Table 2, stomatal density under the circumstance with the use of furrow with organic matter was higher than density without furrow with organic matter. The stomatal density of Situ Patenggang with the use furrow with organic matter is the highest compared to others. Opening and closing stomata is a plant mechanism in obtaining and releasing gas. The condition of low water availability in tolerant plants tends to reduce the rate of transpiration by limiting stomata activity. Plants also have a biochemical response with osmoregulation to maintain cell turgor. This response allows the plant to be able to open the stomata and carry out its photosynthetic activity. In addition, the characteristics of plant stomata are closely related genetically. Guo et al. (2012) have stated that reducing osmotic regulation to maintain cell turgor as of physiological and biochemical processes remain normal under drought stress. Stomatal density of all varieties with furrow + organic matter is higher than without furrow + without organic matter. It indicates that the stomata are affected of water availability. Drought has caused decrease in the number of stomata and other physiological response.

The rate of transpiration and closing and opening of the stomata is a factor that is strongly associated with gas exchange. Therefore, the factors can be used as indicators in determining the resistance to drought (Endres et al., 2010; Sarawa et al., 2014)

The stomatal closure limits $\mathrm{CO}_{2}$ uptake by leaves, in response to either a decrease in leaf turgor and/or water potential (Ludlow and Muchow, 1990; Farooq et al., 2009). Plants respond according to the level of stress experienced and the growth phase. Plants will change the assimilate distribution to support root growth at the expense of the canopy, so that it can increase the capacity of roots to absorb water and inhibit the expansion of leaves to reduce transpiration. In addition, plants can also regulate the opening of the stomata to inhibit water loss through transpiration (Sinaga, 2007).

Based on Yuspradana's (2017) research, mechanism of adaptation to drought stress is by reducing the number of stomata, reducing the opening to decrease transpiration rate. The number of open stomata will decrease due to decreasing soil water capacity.

$\mathrm{Cu}$ is micronutrient that is important in plant metabolism like photosynthesis, respiration, protein and carbohydrate metabolism (Horvarth, 1990; Cetinkaya et al., 2014). The results of soil analysis show 3-20 ppm and that is low $\mathrm{Cu}$ content. $\mathrm{Cu}$ in rice is required to form tillers and seed filling. Each variety has different amount of $\mathrm{Cu}$ absorption. The content of $\mathrm{Cu}$ tissue is sorted from the highest; Situ Patenggang, Ciherang and Situ Bagendit. The content of $\mathrm{Cu}$ tissue for all varieties is low because it is also low in high $\mathrm{pH}$ soil.

According to Table 2, $\mathrm{Cu}$ tissue content under the circumstance with the use of furrow with organic matter is higher than that $\mathrm{Cu}$ tissue content without furrow with organic matter. $\mathrm{Cu}$ tissue content of Situ Bagendit with the use of furrow with organic matter is higher in comparison to others.

$\mathrm{Cu}$ content must be more than $1 \mathrm{ppm}$ available for plants (Idwar et al., 2004). Cu content is normal in plant tissues when it is between 5-20 ppm (Sitorus, 2008). Based on crop physiology, $\mathrm{Cu}$ requirements for each variety are also different. In single factor, Situ Patenggang is able to remain physiologically normal in general than Ciherang and Situ Bagendit.

When deficiency of $\mathrm{Cu}$ occurs, symptoms on the leaves appear followed by brown spots due to 
necrosis. This condition causes the colour of the leaves to be rather blue and chlorosis occurs on the tip of the leaves. According to Roesmarkam and Yuwono (2002), Cu plays a role in protein and carbohydrate metabolism, if lack of protein occurs, synthesis is disturbed and so are flowering and fertilization. Das (2014) has proposed that $\mathrm{Cu}$ plays an important role in the crop growth by increasing the tillering and pollen viability.

\section{CONCLUSIONS}

The Drought affects plant physiology and can be avoided by using furrow containing organic matters. Situ Patenggang under the circumstance with furrow containing organic matters has the higher physiological capability and has photosynthesis $387.18 \mu \mathrm{mol} \mathrm{CO} 2$ per clump s${ }^{-1}$, transpiration $3038.50 \mathrm{mg}$ per clump per second and $\mathrm{CO}_{2} 721.11 \mathrm{~mol} \mathrm{CO}$ clump per mol. There are different plants requirement for $\mathrm{Cu}$ among varieties.

\section{REFERENCES}

Agus, F., Irawan, I., Suganda, H., Wahyunto, W., Setiyanto, A., \& Kundarto, M. (2006). Environmental Multifunctionality of Indonesian Agriculture. Paddy and Water Environ, 4(4), 181-188. https://doi.org/ 10.1007/s10333-006-0047-5

Anshar, M., Tohari, Sunaminto, B H., \& Sulistyaningsih, E. (2011). Pengaruh Lengas Tanah Terhadap Pertumbuhan dan Hasil Tiga Varietas Lokal Bawang Merah pada Ketinggian Tempat Berbeda. Agroland Jurnal Ilmu-ilmu Pertanian, 18(1): 8-14. Retrieved from http://jurnal.untad.ac.id/jurnal/index.php /AGROLAND/article/view/310

Asfafuddin \& Muatsih, S. (2015). Pengaruh Dosis Pupuk Nitrogen dan Jarak Tanam terhadap Pertumbuhan Kara Benguk (Mucuna pruriens L.) untuk Menekan Gulma pada Kebun Sawit Belum Menghasilkan. Retrieved from http:// unihaz.ac.id/upload/all/LAP._PENELITIAN_ _BENGUK___ASFARUDDIN_-_SRI_ MULATSIH_1.pdf

Astuti, R. E. F. (2018). Anatomi Paradermal Daun Enam Jenis Tumbuhan Paku Marga Pteris. Bogor Agricultural University (IPB). Retrieved from https://repository.ipb.ac.id/ handle/123456789/95632
Azadi, H., Ho, P., Hafni, E., Zarafshani, K., \& Witlox, F. (2011). Multi-Stakeholder Involvement and Urban Green Space Performance. Journal of Environtmental Planning and Management, 54(6): 785-811. https://doi.org/10.1080/09640568.2010.53051 3

Balai Besar Penelitian Tanaman Padi (BB Padi). (2007). Deskripsi Varietas Padi. Sukamandi: Balai Besar Penelitian Tanaman Padi. Retrieved from https://bbpadi.litbang.perta nian.go.id/index.php/varietas-padi/inbridapadi-gogo-inpago/situ-bagendit

Balai Penelitian Tanah. (2009). Petunjuk Teknis: Analisis Kimia Tanah, Tanaman, Air, dan Pupuk. (2nd ed.). Retrieved from http:// balittanah.litbang.pertanian.go.id/ind/dokume ntasi/juknis/juknis_ kimia2.pdf

Cetinkaya, H., Seckin Dinler, B., \& Tasci, E. (2014). Investigation of Comparative Regulation on Antioxidant Enzyme System under Copper Treatment and Drought Stress in Maize (Zea mays; L.). Notulae Botanicae Horti Agrobotanici Cluj-Napoca, 42(2), 363371. https://doi.org/10.15835/nbha4229632

Cornic, G. (2000). Drought Stress Inhibits Photosynthesis by Decreasing Stomatal Aperture-not by Effecting ATP Synthesis. Plant Science, 5(5), 758-762. https://doi.org/ 10.1016/S1360-1385(00)01625-3

Das, S. K. (2014). Role of Micronutrient in Rice cultivation and management strategy in organic Agriculture - A Reappraisal. Agricultural Sciences, 5(9), $765-769$. Retrieved from https://m.scirp.org/papers/ 48363

Donggulo, C. V., Lapanjang, I. M., \& Made, U. (2017). Pertumbuhan dan Hasil Tanaman Padi (Oryza sativa L) pada Berbagai Pola Jajar Legowo dan Jarak Tanam. Agroland Jurnal Ilmu-ilmu Pertanian, 24(1), 27-35. Retrieved from http://jurnal.untad.ac.id/jurnal/index.php /AGROLAND/article/viewFile/8569/6801

Dwidjoseputro, D. (1985). Pengantar Fisiologi Tumbuhan. Jakarta: Gramedia Pustaka Utama.

Efendi, R. (2009). Metode dan karakter seleksi toleransi genotipe jagung terhadap cekaman kekeringan. Bogor Agricultural University (IPB). Retrieved from https://repository.ipb. 
ac.id/handle/123456789/5247

Endres, L., Silva, J. V., Ferreira, V. M., \& Barbosa, G. V. D. (2010). Photosynthesis and Water Relations in Brazilian Sugarcane. The Open Agriculture. 4(1), 31-37. http://dx.doi. org/10.2174/1874331501004010031

FAO. (1989). Forestry and Food Security. Rome: Food and Agriculture Organization. Retrieved from http://www.fao.org/3/T0178E/T0178E0 0.htm

Farooq, M., Wahid, A., Kobayashi, N., Fujita, D., Basra, S. M. A. (2009). Plant drought stress: effect, mechanism and management. Agronomy for Sustainable Development, 29(1), 185-212. https://doi.org/10.1051/agro: 2008021

Felania, C. (2017). Pengaruh Ketersediaan Air terhadap Pertumbuhan Kacang Hijau (Phaseolus radiatus). Seminar Nasional Pendidikan Biologi, 131-138. Yogyakarta: Jurusan Pendidikan Biologi, Fakultas MIPA, Universitas Negeri Yogyakarta. Retrieved from http://seminar.uny.ac.id/sembiouny2017/ prosiding/pengaruh-ketersediaan-air-terhadap -pertumbuhan-kacang-hijau-phaceolusradiatus

Fischer, K. S., \& Fukai, S. (2003). How Rice Responds To Drought. In: K. S. Fischer, R. Lafitte, S. Fukai, G. Atlin and B. Hardy. Breeding Rice for Drought Prone Environments. (pp. 32-36). Los Banos: International Rice Research Institute.

Gardner. (1991). Fisiologi Tanaman Budidaya. Jakarta: UI Press.

Gunawan, A. R. \&S. Purwaningsih. (2015). Komposisi Vegetasi pada Agroforestri Kencur di Wilayah Priangan Timur, Jawa Barat. Prosiding Seminar Nasional Agroforestry 2015 Inovasi Agroforestry Mendukung Kemandirian Bangsa, 317-322. Ciamis: Balai Penelitian dan Pengembangan Teknologi Agroforestry bekerjasama dengan Fakultas Pertanian Universitas Padjadjaran, World Agroforestry Centre (ICRAF), Fakultas Kehutanan Universitas Winaya Mukti, Masyarakat Agroforestri Indonesia, dan Perum Perhutani.

Guo, L., Ghassemian, M., Komives, E. A., \& Russell, P. (2012). Cadmium-Induced
Proteome Remodeling Regulated by Spc1/ Sty1 and Zip1 in Fission Yeast. Toxicological Sciences, 129(1), 200-212. https://doi.org/ $10.1093 /$ toxsci/kfs 179

Hafif, B. (2016). Optimasi potensi lahan kering untuk pencapaian target peningkatan produksi padi satu juta ton di provinsi lampung. Litbang Pertanian. 35(2), 81-88. http://dx.doi.org/ 10.21082/jp3.v35n2.2016.p81-88

Hairiah, K., Sardjono, M. A., \& Sabarnudin, S. (2003). Pengantar Agroforestri. Bogor: World Agroforestry Centre (ICRAF) Southeast Asia. Retrieved from http://www.worldagroforestry. org/sea/Publications/files/lecturenote/LN0001 -04.pdf

Halder, K. P., \& Burrage, S.W. (2004). Effect of Drought Stress of Photosynthesis and Leaf Gas Exchange of Rice Grown in Nutrient Film Technique (NFT). Pakistan Journal of Biological Science, 7(4), 563-565. http://dx. doi.org/10.3923/pjbs.2004.563.565

Horváth, G., Droppa, M., Wolak, A., Horváth, L. I., \& Farkas, T. (1987). The Role of $\mathrm{Cu}$ in the Regulation of the Photosynthetic Electron Flow. In Progress in Photosynthesis Research (pp. 569-572). Dordrecht: Springer Netherlands. https://doi.org/10.1007/978-94009-3535-8_135

Idjudin, A. A., \& Marwanto, S. (2008). Reformasi pengelolaan lahan kering untuk mendukung swasembada pangan. Jurnal Sumberdaya Lahan, 2(2), 115-125. Retrieved from http://webcache.googleusercontent.com/searc $\mathrm{h}$ ?q=cache:http://balittanah.litbang.pertanian. go.id/ind/dokumentasi/lainnya/abbas.pdf

Idwar, Saputra, S. I., Hamzah, A, Dahono, Eliartati, \& Zulkifli. (2004). Keragaan dan pertumbuhan padi sawah (Oryza Sativa, L) varietas IR-64 di tanah gambut yang diberi dolomit dan tembaga $(\mathrm{Cu})$ melalui daun. Jurnal Sagoe. 3(1), 45-50. Retrieved from https://ejournal.unri.ac.id/index.php/JSG/artic le/view/701

Kavita, A., Somashekar, R., \& Nagaraja, B. (2015). Urban expansion and loss of Agriculture land - A case of Bengaluru city. International Journal of Geomatics And Geosciences, 5(3), 492-498. Retrieved from http://www.ipublishing.co.in/jggsarticles/volfi 


\section{ve/EIJGGS5042.pdf}

Kementrian Pertanian. (2016). Data Lima Tahun Terakhir. Retrieved from http://www.perta nian.go.id/home/?show=page $\&$ act=view\&id= 61.

Lopez, E., Bocco, G., Mendoza, M., \& Duhau, E. (2001). Predicting Land-cover and land-use Change in The Urban Fringe A Case in Morelia City, Mexico. Landscape and Urban Planning, 55(4), 271-285. https://doi.org/ 10.1016/S0169-2046(01)00160-8

Loveless, A. R. (1987). Prinsip-prinsip Biologi Tumbuhan untuk daerah Tropik. Jakarta: Gramedia Pustaka Utama.

Ludlow, M. M., \& Muchow, R. C. (1990). A Critical Evaluation of The Traits for Improving Crop Yields in Water Limited Environments. Advance Agronomi, 43, 107153. https://doi.org/10.1016/S0065-2113(08)6 0477-0

Maisura, Chozin, M. A. , Lubis, I., Junaedi, A., \& Ehara, H. (2015). Laju Asimilasi Bersih dan Laju Tumbuh Relatif Varietas Padi Toleran Kekeringan Pada Sistem Sawah. Jurnal Agrium. 12(1), 10-15. https://doi.org/10.29 103/agrium.v12i1.376

Mapegau. (2006). Pengaruh Cekaman Air Terhadap Pertumbuhan dan Hasil Tanaman Kedelai (Glycine max L. Merr). Jurnal Ilmiah Kultura, 4l(1), 43 - 49. Retrieved from http:// repository.usu.ac.id/handle/123456789/19951

Maryani, A. T. (2012). Pengaruh Volume Pemberian Air terhadap Pertumbuhan Bibit Kelapa Sawit di Pembibitan Utama. Bioplantae, 1(2), 64-74. Retrieved from https://online-journal.unja.ac.id/bioplante/ article/view/1807

Mayrowani, H. \& Ashari. (2011). Pengembangan Agroforestry Untuk Mendukung Ketahan Pangan dan Pemberdayaan Petani Sekitar Hutan. Forum penelitian Agro Ekonomi, 29(2), 83-98. http://dx.doi.org/10.21082/fae. v29n2.2011.83-98

Mitra, J. (2001). Genetics and genetic improvement of drought resistance in crop. Plants Current Science, 80(6), 758-763. Retrieved from https://www.jstor.org/stable/ 24105661?seq=1\#page_scan_tab_contents
Nayyar, H., \& Gupta, D. (2006). Differential Sensitivity of C3 and C4 Plants to Water Deficit Stress: Association With Oxidative Stress and Antioxidants. Journal. Environment Experimental. Botany, 58(1-3), 106-113. https ://doi.org/10.1016/j.envexpbot.2005.06.021

Perum Perhutani. (2002). Petunjuk Pelaksanaan Pengelolaan Sumberdaya Hutan Bersama Masyarakat di Unit I Jawa Tengah. Semarang: Perum Perhutani.

Putra, S. (2012). Pengaruh Pupuk NPK Tunggal, Majemuk dan Pupuk Daun terhadap Peningkatan Produksi Padi Gogo Varietas Situ Patenggang. Agrotrop : Journal on Agriculture Science,2(1), 55-61. Retrieved from https://ojs.unud.ac.id/index.php/agrotrop /article/view/6241

Quilambo, O. A., \& Scott, P. (2004). Proline content, water retention capability and cell membrane integrity as parameters for drought tolerance in two peanut cultivars. South African Journal of Botany, 70(2), 227-234. https://doi.org/10.1016/S0254-6299(15)30239 $-8$

Roesmarkam, A., \& Yuwono, N. W. (2002). Ilmu Kesuburan Tanah. Yogyakarta: Kanisius.

Rondhi, M., Pratiwi, P. A., Handini, V. T., Sunartomo, A. F., \& Budiman, S. A. (2018). Agricultural Land Conversion, Land Economic Value, and Sustainable Agriculture: A Case Study in East Java, Indonesia. Land, 7(148), 1-19. https://doi.org/10.3390/land704 0148

Rosadi, F. N. (2013). Studi Morfologi dan Fisiologi Galur Padi (Oryza sativa L.) Toleran Kekeringan. IPB (Bogor Agricultural University). Retrieved from https://repository. ipb.ac.id/handle/123456789/63761

Rosenberg, N. J., Blad, B. L., \& Verma, S. B. (1983). Microclimate: the biological environment. Wiley. Retrieved from https://www.wiley.com/en-us/Microclimate\% $3 \mathrm{~A}+$ The+Biological+Environment $\% 2 \mathrm{C}+2 \mathrm{nd}+$ Edition-p-9780471060666

Salisbury, F. B., \& Ross, C. W. (1997). Fisiologi Tumbuhan (Jilid 3). Bandung: Institut Teknologi Bandung.

Sarawa, M. Arma, J., \& Mattola, M. (2014). 
Pertumbuhan Tanaman Kedelai (Glycine max L. Merr) Pada Berbagai Interval Penyiraman Dan Takaran Pupuk Kandang. Jurnal Agroteknos, 4(2), 786. Retrieved from http:// faperta.uho.ac.id/agroteknos/Daftar_Jurnal/20 14/2014-2-02-SARAWA.pdf

Sinaga, R. (2007). Analisis Model Ketahanan Rumput Gajah Dan Rumput Raja Akibat Cekaman Kekeringan Berdasarkan Respons Anatomi Akar Dan Daun. Jurnal Biologi Sumatera, 2(1), 17-20. Retrieved from http:// repository.usu.ac.id/handle/123456789/17545

Sitorus, S. R. P. (2008). Pengelolaan Sumberdaya Lahan. Institut Pertanian Bogor.

Smith, J. (2010). Agroforestry: Reconciling Production with Protection of the Environment, A Synopsis of Research Literature. Newbury: Organic Research Centre, Elm Farm, Hamstead Marshall. Retrieved from http://orgprints.org/18172/1/ Agroforestry_synopsis.pdf

Soleh, M. A. (2017). Overestimasi penggukuran gas exchange tanaman dengan menggunakan Photosynthesis Analyzer Li-6400. Jurnal Kultivasi, 16(1), 255-259. Retrieved from https://www.researchgate.net/publication/319 057394_Overestimasi_penggukuran_gas_exc hange_tanaman_dengan_menggunakan_Phot osynthesis_Analyzer_Li-6400

Stace, C. A. (1965). Cuticular Studies as an Aid to Plant Taxonomy. Bulletin of the British Museum (Natural History), 4, 3-78.
Sugiarto, A., Marisa, H., \& Sarno. (2018). No Title. In Pemanasan Globaldi Sumatera Selatan dan Peningkatan Suhu Udara yang Terjadi: Permodelan Pengaruhnya terhadap Transpirasi Lansium domesticum Corr. Palembang: Jurusan Biologi, Fakultas Matematika dan Ilmu Pengetahuan Alam, Universitas Sriwijaya. https://doi.org/10.31 227/osf.io/st4eh

Sujinah \& Jamil, A. (2016). . Mekanisme Respon Tanaman Padi terhadap Cekaman Kekeringan dan Varietas Toleran. Iptek Tanaman Pangan, 11(1), 1-8. Retrieved from http://ejurnal. litbang.pertanian.go.id/index.php/ippan/article /view/5634

Suryani, E. \& Dariah, A. (2012). Peningkatan Produktivitas Tanah Melalui Sistem Agroforestri. Peningkatan Produktivitas Tanah Melalui Sistem Agroforestri. Jurnal Sumberdaya Lahan, 6(2), 101-109. Retrieved from http://ejurnal.litbang.pertanian.go.id/in dex.php/jsl/article/view/6394

Yoshida, S. (1981). Fundamental of Rice Crop Science. Philippines: The International Rice Research and Institute. Retrieved from http://books.irri.org/9711040522_content.pdf

Yuspradana, R. (2017). Toleransi Tanaman Padi (Oryza sativa L.) dengan Perlakuan Cendawan Endofit Terhadap Cekaman Kekeringan. Bogor Agricultural University (IPB). Retrieved from https://repository.ipb. ac.id/handle/123456789/91210 